\title{
Defining the Distinctiveness of Urban Heritage Identity: Chiang Mai Old City, Thailand
}

\author{
Natthakit Phetsuriya *(D) and Tim Heath \\ Department of Architecture and Built Environment, University of Nottingham, University Park, \\ Nottingham NG7 2RD, UK; lazth@nottingham.ac.uk \\ * Correspondence: natthakit.phetsuriya@nottingham.ac.uk
}

\section{check for}

updates

Citation: Phetsuriya, Natthakit, and Tim Heath. 2021. Defining the Distinctiveness of Urban Heritage Identity: Chiang Mai Old City,

Thailand. Social Sciences 10: 101. https://doi.org/10.3390/ socsci10030101

Received: 16 January 2021

Accepted: 2 March 2021

Published: 11 March 2021

Publisher's Note: MDPI stays neutral with regard to jurisdictional claims in published maps and institutional affiliations.

Copyright: (C) 2021 by the authors. Licensee MDPI, Basel, Switzerland. This article is an open access article distributed under the terms and conditions of the Creative Commons Attribution (CC BY) license (https:// creativecommons.org/licenses/by/ $4.0 /)$.

\begin{abstract}
Distinctiveness is a fundamental part of defining place identity. This paper aims to define the identity of place through the distinctiveness of the urban heritage of Chiang Mai Old City, Thailand. Chiang Mai Old City has unprecedented levels of diversity and a cultural dynamics related to its intangible and tangible urban heritage. Moreover, the city is in the important stage of being nominated as a new World Heritage Site of UNESCO, with the city's distinctiveness being significant in supporting further heritage management strategies. The research presented in this paper mainly focuses on how local people interpret and understand the urban heritage identity of Chiang Mai Old City. This has been achieved through surveys of four hundred participants who live in the Old City and a two-way focus group with five participants in each group. The results provide seven aspects to describe the distinctiveness of Chiang Mai Old City. Moreover, the results can also be used to develop an assessment indicator for defining the distinctiveness of other cities through the engagement of local people.
\end{abstract}

Keywords: urban heritage identity; distinctiveness; Chiang Mai

\section{Introduction}

The concept of an identity of a particular place has been broadly studied by many researchers. Most scholars have attempted to define a genuine identity in terms of both tangible and intangible aspects in cities. Proshansky et al. (1983) described place identity as a repository of emotions and relationships to a place which reflect the meaning, a sense of belonging and the wellness of people in places. Furthermore, in an urban environment study, place identity can be defined by activities or events and the physical environment (Cheshmehzangi and Heath 2012). Place identity is also a paradigm to define the identity of a person or people through a place (Proshansky et al. 1983).

Chiang Mai Old City was nominated and placed on the tentative list for UNESCO heritage sites in 2015 and is in the process of nomination as a new heritage site (UNESCO 2020). However, the city has been encountering a loss in its identity of place due to rapid and uncontrolled urbanization (Moe 2001; UNESCO 2020). Indeed, Chiang Mai Old City is facing the loss of its identity, it included a loss in its urban heritage identity and the loss of townscape characteristic (Srinurak and Auttarat 2013). As a city, it also faces loss of power in terms of the political and cultural domination by Bangkok. However, most of the architects in northern Thailand have attempted to restore the city's identity through the "Cultural Heritage" of the city's urban space (Johnson et al. 2013) following the restoration project of the former Lanna King Palace (Wieng Kaew) in the center of Chiang Mai Old City, which was replaced by the Chiang Mai Women's Correctional Institute. The palace was a sign of the political domination of the Lanna in 1917 A.C (Thai PBS 2020).

Currently, The Chiang Mai Heritage Team has completed the three criteria for nomination of Outstanding Universal Value: firstly, (i) the urban planning of Chiang Mai Old City is reflected upon as a masterpiece of human creative genius, secondly, (ii) the "Lanna Civilization" is still living and is known in the present through the uniqueness of 
Lanna traditions such as the City Pillar worship ceremony and the City Guardian worship ceremony, and the last criteria (iii) the extraordinary architecture of the Golden Age of the Lanna Kingdom can still be viewed today (UNESCO 2020). The dossier also reported the authenticity of the city in terms of both tangible and intangible aspects. The uniqueness of its urban planning was considered tangible authenticity compared to former ancient cities in the northern region. The uniqueness of culture and traditions was mentioned as the city's intangible authenticity (UNESCO 2020) According to Richard Engelhardt, a former regional advisor for UNESCO, "Unlike historical sites such as Ayutthaya or Sukhothai, Chiang Mai is a living breathing city, with all the urban complications that go with it" (Werayutwattana 2019, p. 1). The Living Heritage approach is to preserve continuity and to promote local knowledge, practices, perspectives and traditional skills (Tunprawat 2009). However, to defining Chiang Mai's urban heritage is a challenge that involves exploring the distinctiveness of the living city through the local people who inhabited in the city.

The essential aspect of shaping the identity of a place is the distinctiveness and the appearance of a place. These two aspects are what people associate with characterizing a place and can distinguish one place from another, particularly in relation to urban heritage (Ginting and Wahid 2017). The identity of a place is comprised of the attributes of the physical environment, the variety of human activities or events and cultural influence in terms of meaning and associations that can help to define the identity and quality of an urban environment within its context. However, in terms of defining the distinctiveness of a place, history plays a significant role (Kalandides 2011). Urban identity is an important topic that depends upon an understanding of spatial theories with inter-relationship development: it's a relationship between socio-environmental values and the essence of the place (Cheshmehzangi and Heath 2012; Shamsuddin 1997).

This research will demonstrate how cross-disciplinary methods, consisting of qualitative and quantitative methods, can assist in defining the distinctiveness of a place. Furthermore, this research will contribute to the understanding of the distinctiveness of Chiang Mai Old City and propose further theoretical development in defining the distinctiveness of living cities, particularly those with many religious sites such as Luang Prabang city in Laos, Hoi-An city in Vietnam, Penang city in Malaysia and Vigan city in the Philippines. In addition, this paper provides a broader perspective on how identities and attachment are configured in heritage sites.

\subsection{Distinctiveness}

"... Distinctiveness" "as a social value, an aspect of self-enhancement, a fundamental human need, and a basic property of the construction of meaning within identity"

(Vignoles et al. 2000).

Distinctiveness is an essential aspect in shaping identity, particularly with regards to urban heritage.It can be used as a tool to distinguish cities in an urban study based upon people's experiences (Twigger-Ross and Uzzell 1996). Distinctiveness ultimately includes the long-term evaluation of constructed and natural properties (Carmona et al. 2010). Local distinctiveness is defined as an elusive concept, which in essence includes the particular physical, social and economic features of a location and the relationship of individuals with those features. Carmona et al. (2010, p. 123) note how: "Distinctiveness is concerned fundamentally with preserving and enhancing what is special about a place." Places can be built with specific geographical, physical and environmental features, combined with distinctive cultural factors that manifest in the original form and purpose of the settlement and subsequent human interventions over time. Distinctiveness is then connected to a positive understanding of the uniqueness of a place (Lalli 1992). 
According to El Hosary et al. (2018), local distinctiveness consists mainly of five aspects: natural features, man-made structures, cultural identity and people, food and drinks and crafts and industry (see Table 1). However, in the study of Ginting and Wahid (2017), the authors compare the theory following Breakwell (developed by (Lalli 1992; Lynch 1960; Twigger-Ross and Uzzell 1996). In defining identity, they articulated four variable aspects to investigate distinctiveness: landmarks; uniqueness; particular character; and different perception (see Table 2).

Table 1. Description of local distinctiveness elements (El Hosary et al. 2018).

\begin{tabular}{|c|c|c|c|c|}
\hline \multicolumn{2}{|c|}{ Core Elements } & \multicolumn{3}{|c|}{ Dynamic Elements } \\
\hline Natural Features & Man Made Features & $\begin{array}{l}\text { Cultural identity and } \\
\text { people }\end{array}$ & Food Drink and Crafts & Industry and Business \\
\hline Location & Historic Features & Event & Craft & Manufacturing \\
\hline Topography & Townscape & Language & Artifact & Cultural Industries \\
\hline Natural & Buildings & Tradition & Food & Land uses \\
\hline Landscape & Monument & Famous Person & Drink & Activities \\
\hline Habitat & Transportation & Dressing & & \\
\hline Coastline & & Music & & \\
\hline \multicolumn{5}{|l|}{ Native Plants } \\
\hline Natural Materials & & & & \\
\hline
\end{tabular}

Table 2. Description of local distinctiveness elements (Ginting and Wahid 2017, p. 43).

\begin{tabular}{cccc}
\hline Landmarks & Uniqueness & Particular Character & Different Perception \\
\hline $\begin{array}{c}\text { Respondent's perception of } \\
\text { Landmark of City }\end{array}$ & $\begin{array}{c}\text { Respondent's perception } \\
\text { about attractive place }\end{array}$ & $\begin{array}{c}\text { Respondent's perception } \\
\text { about good place to eat }\end{array}$ & $\begin{array}{c}\text { Respondent's perception of } \\
\text { cultural activity in research } \\
\text { area }\end{array}$ \\
\hline $\begin{array}{c}\text { Respondent's perception of } \\
\text { accessible to visit research } \\
\text { area }\end{array}$ & $\begin{array}{c}\text { Respondent's perception of } \\
\text { historic buildings in research } \\
\text { area }\end{array}$ & $\begin{array}{c}\text { Respondent's perception of } \\
\text { diversity of local product in } \\
\text { research area }\end{array}$ & $\begin{array}{c}\text { Respondent's perception of } \\
\text { tourism facilities in research } \\
\text { area }\end{array}$ \\
\hline
\end{tabular}

\subsection{Urban Heritage}

"Urban heritage can be defined as including other legacies from the past that make a town or city distinctive, such as the arts and crafts, or the rituals, ceremonies and festivals, shared by a community." (Logan 2005, p. 28).

Urban heritage informs identity and is a crucial aspect of informing the memory and value of a place (Howard 2003). Orbasli (2000) also describes urban heritage as an indispensable element of cityscapes that manifest to the past's memory (Orbasli 2000). Urban heritage also relates to global history as its physical appearance represents tangible evidence of previous civilisations' continued existence. Within a spectrum of disciplines such as art history, leisure studies, archaeology, geography, history and the built environment, urban heritage is understood as an integral part of urbanisation, community, social, religious ideals and inter-generational interactions (Urban Heritage 2016). Knowledge and understanding of urban heritage are inseparable from human factors, especially in the built environment, which is often linked to human behavior, memory, local people, tourism, socio-economic and socio-cultural issues.

Urban heritage stimulates a sense of place and place attachment, which are also effective for human behavior (Devine-Wright 2009). Nevertheless, in an urban defining process, human behavior is directly linked to the theory of authenticity. The authenticity of urban heritage is vital in order to recognize potentially dysfunctional conditions. The reconciliation of the interests of the heritage is necessary to confront the other principle of authenticity (Martínez 2017). A significant challenge to urban heritage in contemporary society is the economic desire for urban growth and urban areas' densification. 


\subsection{Urban Identity}

Urban identity is a concept that is not physical but can be correlated with the city's physical, cultural, socio-economic and historical characteristics (Erdoğan and Ayataç 2015). It is the significant factor that is stated after the recall, assessments and a self-identity process by people recognizing the environment. Identity, however, does not provide a sustainable result; it remains the most effective tool for determining the validity of social meaning for a while (Hartanti 2014). Using a historic, distinctive urban shape, architectural style, design solutions and ornaments, while using local building materials and construction techniques also expresses urban identity. Historic environments, through their architecture can create a distinctive visual impression of the city. In addition to the development of new buildings influenced by the past, historical districts' renovation will play a significant role in rebuilding present cities and the loss of urban identities (Boussaa 2017).

However, physical elements only partially enable an understanding of urban identity. The variety of activities, events and users that enliven public places and exhibit urban identity are also a crucial part of the urban identity (Erdoğan and Ayataç 2015). Furthermore, the perception of urban objects and cities' uniqueness that combine environmental, historical, socio-cultural, functional and spatial values in urban space are essential. (Arbak 2005). The essential importance of people's experience in the creation of urban identity: "Functions and behaviors related to urban physicality are the foundation of urban identification" and following human activities through history, urban symbolism or meaning is created" (Relph 2007). To conclude, the urban identity maintains the idea of identity, which expresses a relatively mature description that includes the feelings, meanings and memory of human to tangible and intangible elements. (Rifaioğlu and Şahin Güçhan 2007).

This section has reviewed the relation of the study topics. It is clear from the research reviewed that identity assessment is very immersed and widely studied throughout the cities. It is also clear that the field of studies just regarding the physical attributes and human behavior that people express in the cities. Urban heritage identity is still being debated, though and continues to be problematic in the discourse of urban heritage, sense of place, place attachment and human perception study. This field of study is critical as its center is concerned with helping local people understand their city's valuable. To acknowledge the local people to become a part of the study is essential in improving and preserving their city's identity.

\section{The Study Case}

Chiang Mai Old City

In the thirteenth century, a new kingdom emerged in Southeast Asia's northern region, with a loose group of domains and city-states combining into the Lan Na Kingdom. This collective name implies that the Lanna Kingdom evolved and reached its high golden age as a million rice fields. The physical form of the Lanna capital Chiang Mai is a perfect rectangular shape of $1.6 \mathrm{~km}$. by $1.5 \mathrm{~km}$. There are five gates and four forts along the city walls, demonstrating the city's hierarchical order. Before King Mungrai moved from Wieng Kum Kam to the city on April 12, 1296, the former, more irregular city wall in the solar calendar can be seen in Figure 1b. The city was strategically located between the Kok and Ping river valleys, enabling it to control the city and trading to the south (Siam) and the north (Yunnan, Chiang Saen) (Ongsakul et al. 2005). 


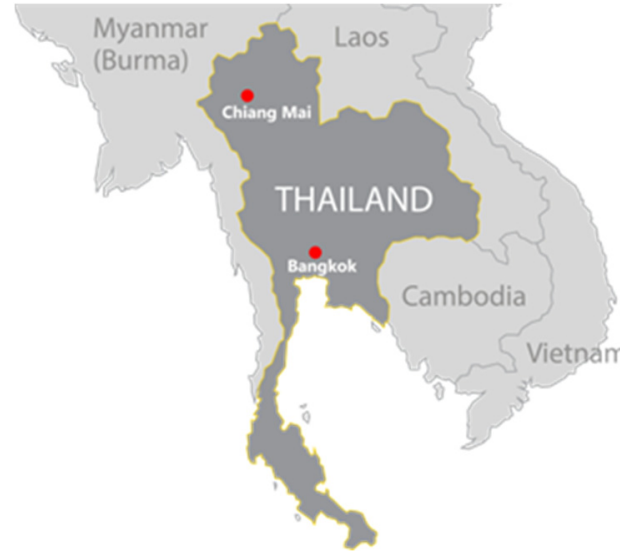

(a)

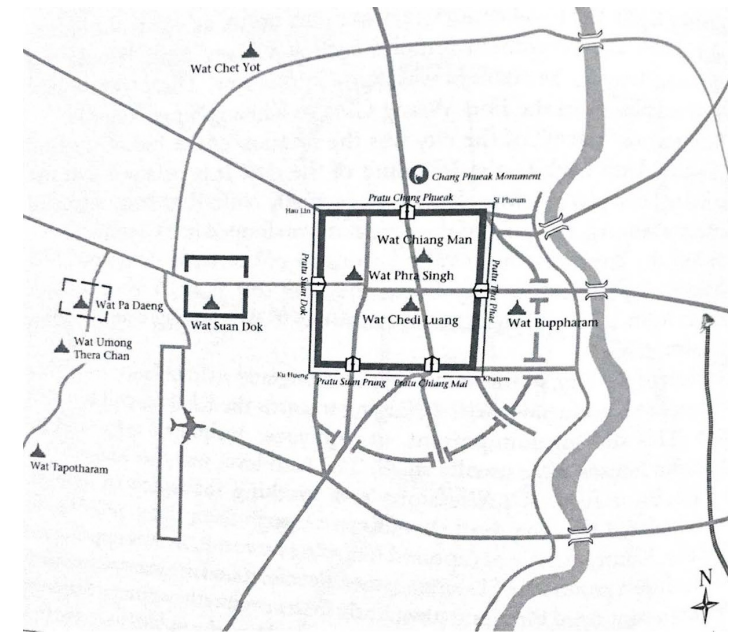

(b)

Figure 1. (a): The location of Chiang Mai in Thailand (Author). (b) The Map of Chiang Mai with the significant places (Ongsakul et al. 2005, p. 68).

A new era for the Thai Yuan people emerged on Chiang Mai city's founding with the city created as the new kingdom's political, economic, social and cultural center (Ongsakul et al. 2005). Chiang Mai, the name of which means "the new city", was founded in 1296 CE. Initially, King Mungrai developed unique social engineering concerned with rituals that incorporated ancient local mountain spirits' conciliation with modern Buddhist merit-making activities to ensure peace, stability and empowerment. Figure 2 illustrates the timeline of the emerging of ancient cities in Thailand; Lanna urban planning was mixed the local belief and triphum ideology from Sukothai city, which was the capital of the first kingdom of Siam (Thailand) in the 13th-14th century. Currently, Sukothai city was nominated as a World Heritage Site in 1991 (UNESCO 2020). Unfortunately, Sukothai city was deserted leaving the ancient ruins of the building as an outdoor exhibition without life in the city.

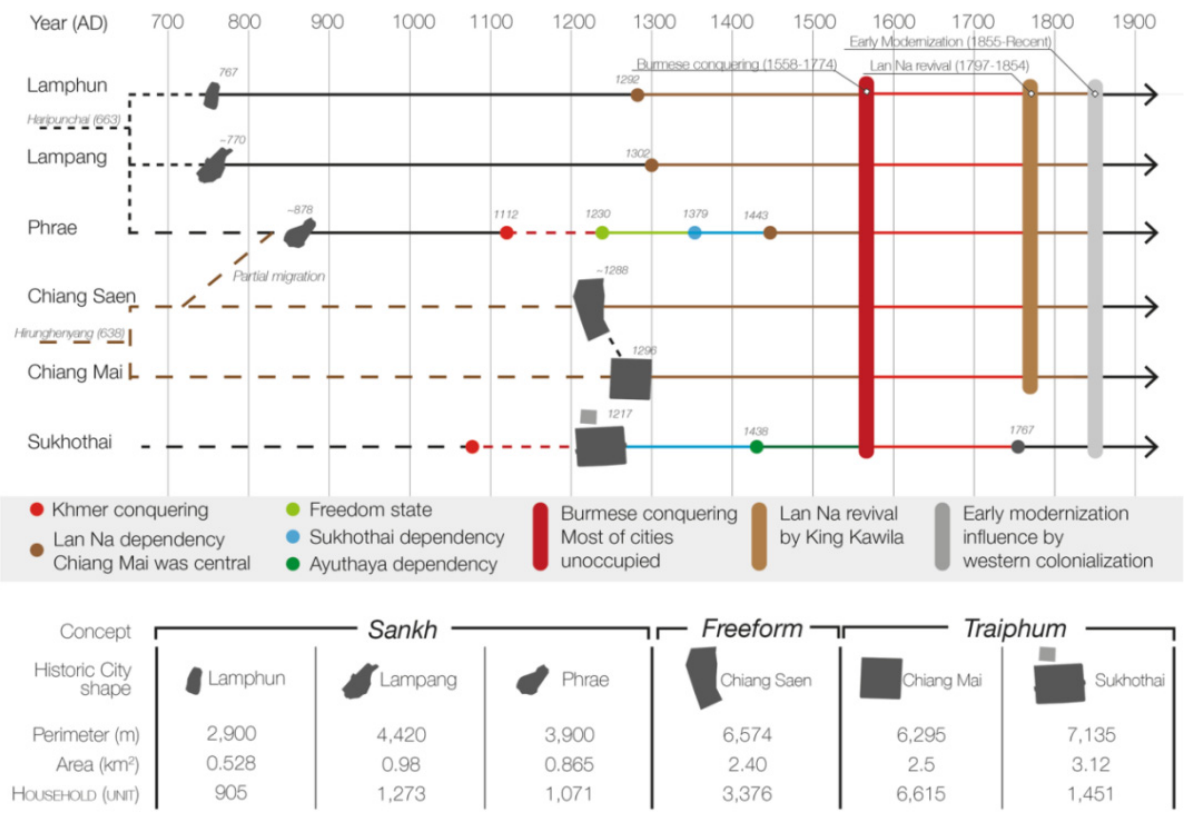

Figure 2. Chronology of the Lan Na cities (Srinurak and Mishima 2017, p. 5). 
According to cosmological principles, King Mangrai built Chiang Mai as a city surrounded by satellite towns and, therefore, likened to the center of the universe. Following the cosmological beliefs, the Chedi Luang Temple or "Mount Meru" was located in the middle of the city as the "center of the universe" and it was also considered the spiritual center of the city. Moreover, it was surrounded by eight satellite temples similar to the eight planets of cosmological lore. Many other places were also considered powerful and sacred in the center of the city, including the Pillar of Inthakhin City, the Yang tree, Kumphan Asura (an ogre who was the city's protector) and the palace. These helped to build a sense of heritage for Chiang Mai and gave it a much higher status than the satellite towns. Ongsakul et al. (2005) argue that the city's significance was multifaceted. It was a permanent capital, a new idea in Thai Yuan (Tai) culture. However, the Thai Yean people, who were the initial group of race in the area, had beliefs about "City as a body and a soul" related to the direction of City Gates and the hierarchy of land use.

Chiang Mai's UNESCO nomination dossier reported that the city is an exceptional testimony for the most advanced "Tai" town planning with the highest mixture of different ideologies at the time (Figure 3). Furthermore, the importance of Chiang Mai historical city's town planning is affirmed by physical evidence related to its urban structures, such as its architecture and the religious buildings. Currently, the Cultural and Natural Environment Management Bureau of Thailand announced the conservation territory of Chiang Mai Old City (Figure 4), the Chiang Mai council use the same territory in the Municipal Building Law in the old city.

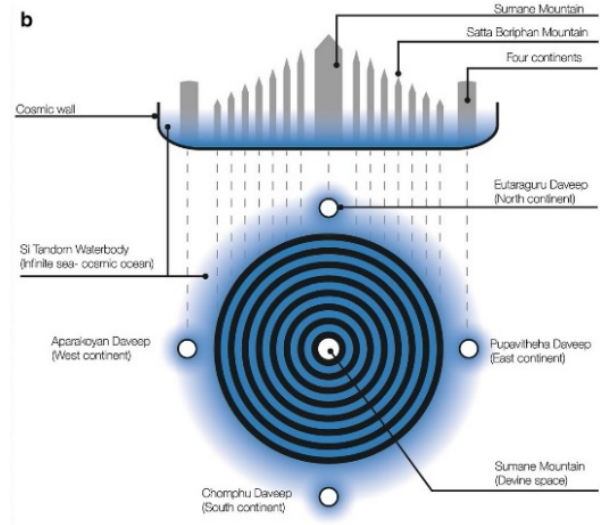

(a)

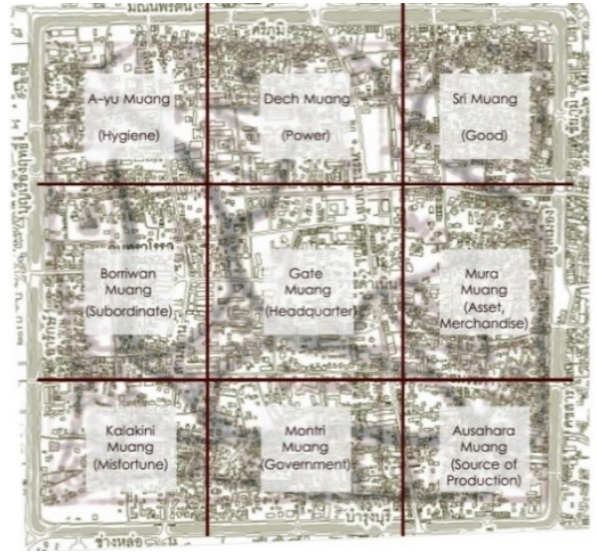

(b)

Figure 3. (a): Triphum Concept (Srinurak and Mishima 2017, p. 4). (b) The simulation of the city map to the belief of "body and soul" of city and the hierarchy of city doors and city's areas (Author). 


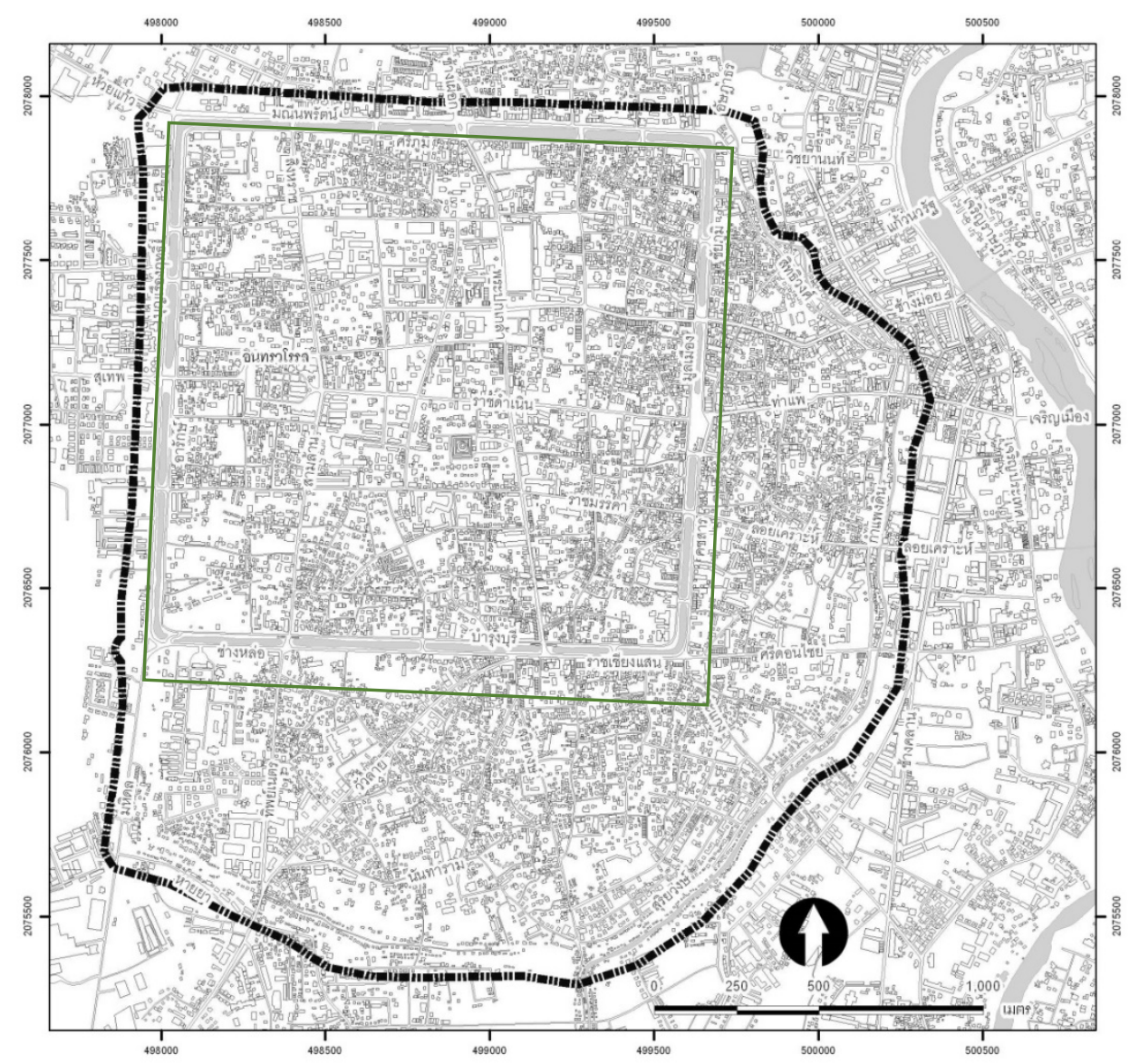

Figure 4. The study area is highlighted in green line, the map of Chiang Mai Old City, Thailand and the boundary of Old City following the Chiang Mai municipal law (Cultural and Natural Environment Management Bureau 2016).

\section{Materials and Methods}

The research utilizes both qualitative and quantitative methods to understand the perception of participants' (specifically Chiang Mai residents) with regard to Chiang Mai Old City. In detail, a questionnaire survey was followed by four-hundred local participants and qualitative two-way focus groups with five participants in each group.

\subsection{Questionnaire}

Questionnaires are one of the most used data collection techniques and, thus, it is used by many social science researchers to analyze perception. The questionnaire is a helpful method and instrument for measuring emotions, moods, actions and attitudes (Shinbira 2017). Questionnaires are mainly used in conducting quantitative research, where the researcher wants to profile the sample in terms of numbers (e.g., the proportion of the sample in different age groups, genders, etc.) or to be able to count the frequency of occurrence of opinions, attitudes, experiences, processes, behaviors, or predictions (Rowley 2011).

\section{Sample Size Questionnaire}

All participants were selected from local people who live or work in the old city and consider themselves "Chiang Mai people". The sample size for the questionnaire was calculated following the Taro Yamane formula (Yamane 1967) often used in survey research. This relates to the process of conducting research using surveys that are sent to survey respondents. The data collected from the surveys is then statistically analyzed to draw meaningful research conclusions. This research uses a face-to-face method. The Bureau 
of Registration Administration of Thailand (2019) stated that Chiang Mai's population (Muang Chiang Mai district) was 127,240 people in 2019. In this research, 0.05 was chosen to signify the margin error (e), resulting in a sample size of 400 participants.

$$
\mathbf{n}=\frac{N}{1+N *(e)^{2}}
$$

$\mathbf{n}=$ signifies the sample size

$N=$ signifies the population being studied

$e=$ signifies the margin error (It could be $0.10,0.50$ or 0.01 )

\subsection{Focus Group}

Focus groups are commonly used and are popular in sociology and social science research (Marshall and Rossman 2003). Focus group approaches are developed out of psychological and marketing traditions but were used more than half a century earlier by social scientists. Focus groups are a type of group discussion or interview where individuals are invited to discuss specific topics in a relatively casual environment so that underlying issues (norms, attitudes and values) that are common to all participants' lives can be uncovered. Compared to the individual interview, the benefit of the focus group is that the researcher may also compare outcomes and interactions between various groups of participants. In this research, the format involved two groups, where the subject was deliberately addressed by one group, while the first group was observed by the other. This type of focus group is usually performed behind a one-way mirror. Without being heard, the observing group and the moderator will track and record the first group's interactions and discussion. Hearing (or watching their interactions) what the other group thinks can also lead the second group to different conclusions than those it would have otherwise reached (Nyumba et al. 2018)

\section{Sample Size Focus Group}

In this study, the participants were voluntarily recruited from posters and public posts on social media. Furthermore, the participants were chosen from the local people who inherited or worked in the old town and regarded themselves as "Chiang Mai people". The number of respondents for discussion is another significant factor. It is generally accepted that between six and eight participants are adequate. Some studies have recorded as few as four participants and as many as fourteen participants. Therefore, ten participants were selected for this research and this was considered broad enough to obtain a spectrum of viewpoints and limited enough not to become disorderly or scattered. The group becomes challenging to handle with more than twelve members and can disintegrate into two or even three small groups, each having their separate discussion (Nyumba et al. 2018).

\subsection{Data Collection and Analysis Process}

In this study, the questionnaire was designed as an open-end questionnaire. It allows people to express what they think in their own words and open-ended questions encourage the respondent to answer in as much depth as they want to and in their own words. The questionnaire for this study was divided into two parts: firstly, to ask the participants to recall as many of the vital places in the Chiang Mai old city as they could; and secondly, to articulate the reasons why they feel attached to those places. The analysis uses the whole counting method $(\mathrm{X})$, which is an all-counting process in data analysis (Huang and Lin 2011).

The focus groups were comprised of local participants in two medium-sized groups of five people. Initially, the moderator introduced the subject of this discussion and asked everyone to participate and reveal their opinions during the discussion. The group members were also told that they were going to be recorded and filmed during the session. The conversation started with an 'icebreaker' where each member briefly introduced 
themselves. The information presented to the groups consisted of the purpose of the study, the map of Chiang Mai Old City and the study's question. The process began with the question (i) What is the distinctiveness of the urban heritage of Chiang Mai Old City?; and (ii) What are the places in the Old City that are important to you? They were also asked to articulate the reasons why these can help to define the urban heritage identity of the Old City? After allowing the participant individually considered their answers. The moderator asked each group to mark the map and discuss the reasons (Figure 5). According to the two-way focus group, the moderator allowed both groups to discuss the reasons and places; this leads to the acknowledgement process and the emergence of critical thinking.

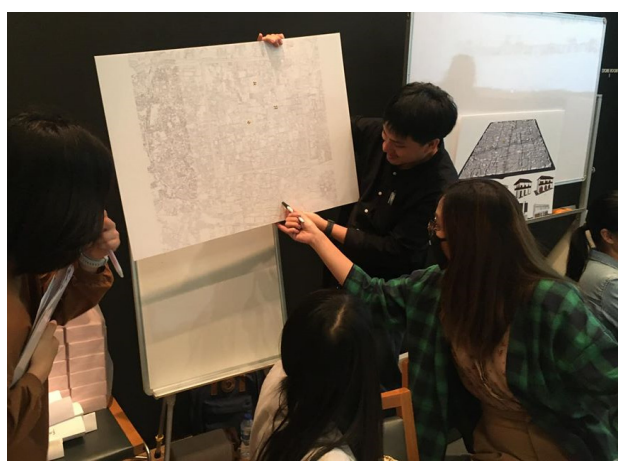

(a)

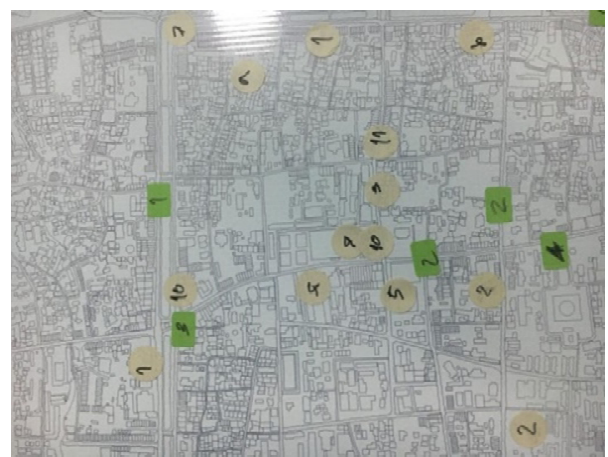

(b)

Figure 5. (a): Focus Group discussion process (Author). (b) Mapping the significant places on Chiang Mai Old City Map (Author).

According to the seven processes of Focus Group Analysis (Table 3), firstly, the study considered the appropriate attention to all types of data, including verbal and non-verbal data such as the specific behavior "smiling to participants 001" rather than just mention on general emotion, such as "happy". Secondly, read through of focus group transcript to identify contents areas and extract all related text also included non-verbal text. In this process, the study identified seven aspects: landmark, identity, historical values, particular characters, everyday life and community. Furthermore, manifest contents separately by sorting each content areas' meaning units, condense text and non-verbal into a description and code them. The coding unit used to categorize into subcategorized according to the similarities of data. This process explores the interaction of each data analysis, including verbal and non-verbal data on a table. The critical phase of the analysis is that all contents must be integrated into "subgroup" and "groups" to conclude the content area's overall results. Finally, to report the results, a text is presented to explain in-depth and a table for a presentation (Table 4) (Nili et al. 2017).

Table 3. The Steps of the Focus Group Data Analysis Framework (Nili et al. 2017, p. 6).

\begin{tabular}{|c|c|}
\hline \multicolumn{2}{|c|}{ 1. Determine and organize theoretically sensitive types of data } \\
\hline \multicolumn{2}{|c|}{ 2. Identify content areas } \\
\hline \multirow{4}{*}{ In each Content Area } & 3. Conduct a manifest analysis of content data \\
\hline & 4. Conduct a latent analysis of content data \\
\hline & 5. Analyze interaction data \\
\hline & 6. Integrate the results in each content area (integrate the results obtained through steps 3 to 5 ) \\
\hline
\end{tabular}


Table 4. The example of focus group analysis in this study (Author).

\begin{tabular}{|c|c|c|c|c|c|}
\hline \multicolumn{6}{|c|}{ Group: Distinctiveness of Urban Heritage of Chiang Mai Old City, Thailand } \\
\hline \multicolumn{2}{|c|}{ Subgroup: Urban factors } & \multicolumn{3}{|c|}{ Subgroup: Culture and Tradition } & Subgroup: Human factors \\
\hline CMU1 & CMU2 & CMU3 & CMU4 & CMU5 & CMU6 \\
\hline (MU1) & (MU2) & (MU3) & (MU4) & (MU5) & (MU6) \\
\hline G1L & G1I & G1HV & G1CA & G1PC & G1C \\
\hline G2L & G2I & G2HV & G2CA & G2PC & G2C \\
\hline GDL & GDI & GDHV & GDCA & GDPC & GDC \\
\hline \multicolumn{3}{|c|}{$\mathrm{CMU}=$ Condensed Meaning Unit } & \multicolumn{3}{|c|}{ MU = Meaning Unit } \\
\hline \multicolumn{3}{|c|}{ GXX = Group (No.)(CMU) } & \multicolumn{3}{|c|}{ GDX = Group Discussion (CMU) } \\
\hline
\end{tabular}

\section{Results}

\subsection{Questionnaire Results}

Table 5 illustrated the results of questionnaire according to the questionnaire asked the participants to recall their memories from their own experiences to indicate the most important places and then give reasons why they feel attached to those places. The results show 38 places, which consists of temples, the palace, urban heritage attributes, walking street, museum, government buildings and some of the nominated sites (blue highlighted).

Table 5. The conclusion of the recalled to the important places in Chiang Mai Old City.

\begin{tabular}{|c|c|c|c|c|c|c|c|c|}
\hline & Name of the Place & $x$ & Landmark & $\begin{array}{c}\text { Historical } \\
\text { Value }\end{array}$ & $\begin{array}{l}\text { Particular } \\
\text { Character }\end{array}$ & $\begin{array}{c}\text { Cultural } \\
\text { Activities }\end{array}$ & $\begin{array}{c}\text { Everyday } \\
\text { Life }\end{array}$ & Identity \\
\hline 1 & Pra Singha Temple & 243 & 11 & 117 & 33 & 76 & 2 & 2 \\
\hline 2 & Chedi Luang Temple & 224 & 4 & 98 & 9 & 107 & 5 & 1 \\
\hline 3 & Three Kings Monument Square & 129 & 21 & 57 & 40 & 3 & 8 & 0 \\
\hline 4 & Tha-Pear Gate Square & 76 & 15 & 23 & 17 & 1 & 12 & 8 \\
\hline 5 & Chiang Mun Temple & 59 & 0 & 37 & 2 & 19 & 1 & 0 \\
\hline 6 & Pun Tow Temple & 48 & 0 & 9 & 5 & 34 & 0 & 0 \\
\hline 7 & Chiang Mai Moat & 44 & 6 & 21 & 7 & 0 & 3 & 8 \\
\hline 8 & Burirad Palace & 29 & 0 & 17 & 11 & 0 & 1 & 0 \\
\hline 9 & Chiang Mai Gate & 27 & 5 & 8 & 8 & 0 & 5 & 1 \\
\hline 10 & Inthakin Temple & 24 & 0 & 16 & 4 & 3 & 1 & 0 \\
\hline 11 & Duang Dee Temple & 22 & 0 & 1 & 15 & 6 & 0 & 0 \\
\hline 12 & Chang Puak Gate & 21 & 4 & 6 & 9 & 0 & 2 & 0 \\
\hline 13 & Larm Chang Temple & 19 & 0 & 8 & 3 & 7 & 1 & 0 \\
\hline 14 & Old City Hall & 19 & 0 & 15 & 4 & 0 & 0 & 0 \\
\hline 15 & Prasart Temple & 17 & 0 & 6 & 7 & 4 & 0 & 0 \\
\hline 16 & Women Correctional Institute & 16 & 0 & 15 & 1 & 0 & 0 & 0 \\
\hline 17 & Suan Dok Gate & 13 & 0 & 6 & 3 & 0 & 4 & 0 \\
\hline 18 & Inthakin Pillar-Gurjan Tree & 12 & 0 & 6 & 1 & 5 & 0 & 0 \\
\hline 19 & Yupparad School & 11 & 0 & 8 & 3 & 0 & 0 & 0 \\
\hline 20 & Sri Phum Fort & 11 & 1 & 1 & 2 & 0 & 7 & 0 \\
\hline 21 & Pan Oun Temple & 10 & 0 & 0 & 3 & 7 & 0 & 0 \\
\hline 22 & San Prung Gate & 10 & 3 & 3 & 0 & 0 & 1 & 3 \\
\hline 23 & U-Mong Temple & 9 & 0 & 1 & 1 & 7 & 0 & 0 \\
\hline 24 & Koun Kha Mah Temple & 8 & 0 & 2 & 1 & 5 & 0 & 0 \\
\hline 25 & Sumpaw Temple & 8 & 0 & 0 & 3 & 5 & 0 & 0 \\
\hline 26 & Sanmuangma Temple & 7 & 0 & 3 & 0 & 2 & 2 & 0 \\
\hline 27 & Dok Aueng Temple & 6 & 0 & 0 & 0 & 5 & 1 & 0 \\
\hline 28 & Wua Lai Walking Street & 6 & 0 & 3 & 3 & 0 & 0 & 0 \\
\hline 29 & Jed Rin Temple & 6 & 0 & 0 & 4 & 0 & 2 & 0 \\
\hline 30 & Chang Tam Temple & 6 & 0 & 0 & 4 & 2 & 0 & 0 \\
\hline 31 & Muen Ran Temple & 5 & 0 & 1 & 0 & 2 & 1 & 0 \\
\hline 32 & Tha Pare Walking Street & 5 & 0 & 3 & 2 & 0 & 0 & 0 \\
\hline 33 & Chai Pra Kiat Temple & 4 & 0 & 1 & 1 & 2 & 0 & 0 \\
\hline 34 & Buak Hard Public Park & 3 & 0 & 0 & 3 & 0 & 0 & 0 \\
\hline 35 & Mung Rai King Stupa & 3 & 0 & 2 & 1 & 0 & 0 & 0 \\
\hline 36 & Ga-Thum Fort & 3 & 1 & 0 & 0 & 0 & 2 & 0 \\
\hline 37 & Gu-Huang Fort & 3 & 1 & 0 & 0 & 0 & 2 & 0 \\
\hline 38 & Hua Rin Fort & 3 & 1 & 0 & 0 & 0 & 2 & 0 \\
\hline
\end{tabular}

\subsubsection{Landmark}

The landmark aspect is the fifth aspect that participants recalled. The participants contributed the emotion and reason for identifying these places in terms of: "It is a landmark of the city"; "It is easy to find this place and also be an assembly point for a 
group of friends"; "The place reminds me to the truly Chiang Mai; "The traveller can find this place easily when visited the old city"; etc. Most of reasons related to the significant of location of the place. This linked to Lynch (1960, p. 101), who identified landmarks as: "A landmark is not necessarily a large object; it may be a doorknob as well as a dome. Its location is crucial: if large or tall, the spatial setting must allow it to be seen; if small, there are certain zones that receive more perceptual attention than other ... " The Three Kings Monument square (Figure 6a) was also recalled for its landmark aspect; it was built 36 years ago and remains the "assembly point" in the center of the city until the present. The Three Kings Monument square (Figure 6a) is called "Kuang" (Northern-Thai dialect). Precisely, the place is located in the city center and it is only one open urban space in the city which has been being used in the sacred ceremony of the city.

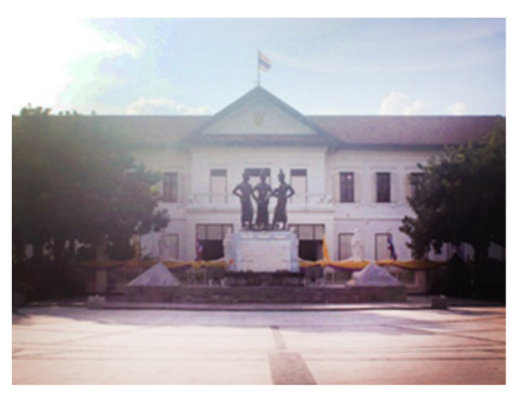

(a)

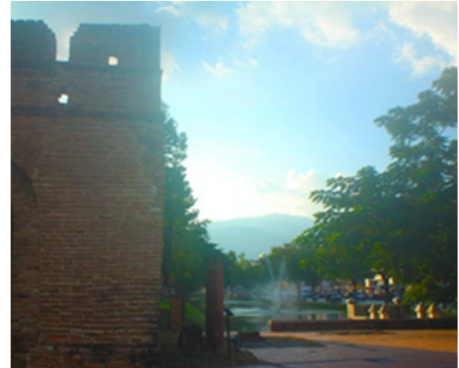

(b)

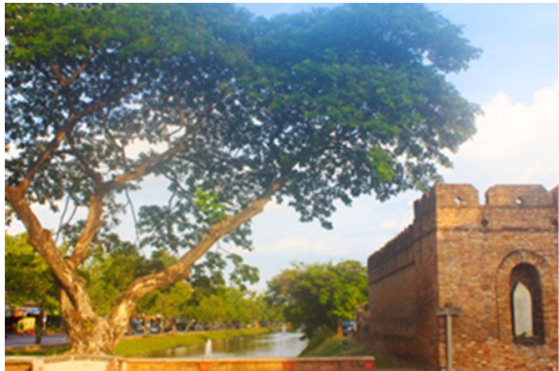

(c)

Figure 6. (a) Three Kings Monument Square (Author); (b) Chiang Mai City Moat (Author); (c) Chiang Mai City Moat (Author).

\subsubsection{Uniqueness \\ Historical Value}

The participants mostly recalled the Historical Value aspect. The participants mentioned words such as "Old place with history" and felt that it is "a valuable place and important". The Pra Singha temple (Figure 7b) was recalled the most of all in terms of the historical value aspect. Furthermore, the participants also revealed their opinions in relation to their historical memory with other places, following comments such as: "It is a special place and knowledgeable place for a generation" and "It was a temple before Siam vanished it". Some participants also mentioned specific places: "It was an important place for the city. The place had been transformed into the city hall when Siam colonized Lanna." However, interestingly a few people recognized specific locations as knowledgeable places and archaeological sites. The results can be related to the definition of historical value in the study of Jeremy C. Wells (2010, p. 3) who mentioned that: "Historical value can be divided into two elements: association of the older built environment with historical events or people from the past and the ability of building fabric to convey information on past cultural practices, such as craftsmanship."

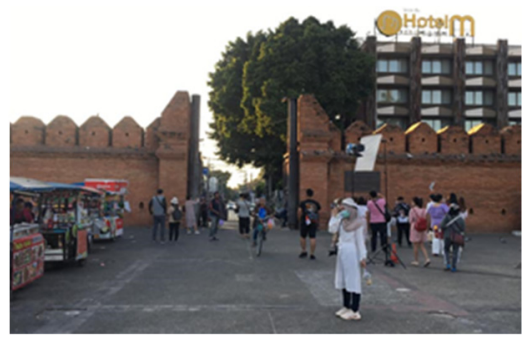

(a)

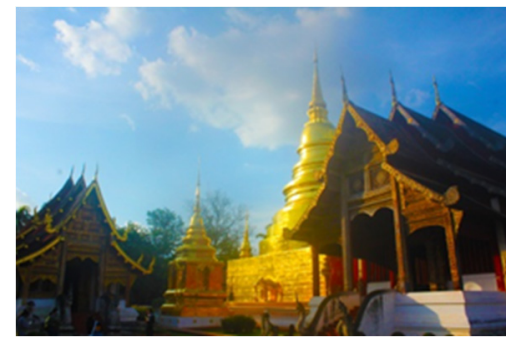

(b)

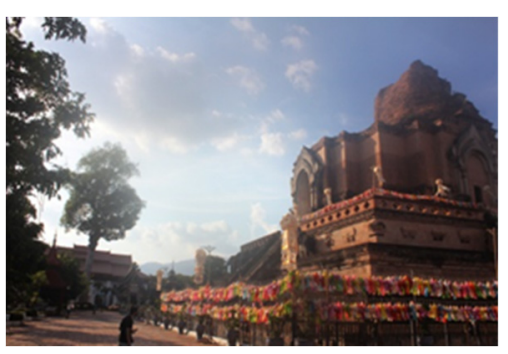

(c)

Figure 7. (a) Tha-Pare Gate Square (Author); (b) Pra singha (Author); (c) Chedi Luang Temple (Author). 
Identity

Tha-Prae Gate Square (Figure 7a) and Chiang Mai Old City Moat (Figure 6b,c) were recalled in relation to the identity aspect. The gate was formally the main gate of the city and is now an urban open space. The Chiang Mai Moat is a unique urban artefact compared to other cities in Thailand. Accordingly famous festivals have always been staged along the moat and the square. Significantly, Lynch (1960, p. 132) identifies "identity as a sense of place which is the extent to which a person can recognize or recall a place as being distinct from other places as having a vivid, or unique, or at least a particular, character of its own". The local Chiang Mai people participating in this survey also expressed their opinions on the importance of Tha-Prae Gate square (Figure 7a) and Chiang Mai Moat (Figure 6b, c), articulating that "the place is an image of the city" and those they "represent reputation of the city". Furthermore, their location is on the main axis of the city and the major street leading to the Pra Singha Temple (Figure $7 \mathrm{~b}$ ) and the famous historical landscape of Chiang Mai's Pra Trad Doi Suthep which is set against the backdrop of Chiang Mai Old City. These findings in this research accord with Rifaioğlu and Şahin Güçhan's (2007) study on the Assessment of Urban Identity Characteristics in Public Places: a case study of Ortaköy Square, Turkey, which mentioned that "identity becomes the main feature that confers unique characteristics to a city or a local place" (Rifaioğlu and Şahin Güçhan 2007, p. 2).

\subsubsection{Particular Character}

The particular character aspect includes unique and distinctive activities, which occur in places. This part categorizes the extraordinary functions that occur in the sites recalled by the participants in the surveys. In this study, 40 people were reminded about The Three Kings Monument square (Figure 6a) as a space for activities. Multiple activities within Chiang Mai old city's spaces were recalled including skateboarding, walking, exercise, walking street, a market in the temple and floral festival. In addition, 18 people recognized the importance of food in the markets and highlighted the famous places for food while visiting those places. The Three Kings Monument square (Figure 6a) was recalled the most due to its location and characteristics as an open space with multi-character utilities. Furthermore, forty people mentioned that "it is located in my neighborhood and reminded me of childhood memories". Additional, this part shows the local people's genuine expression to places that are often hidden by their generally accepted historical importance. The results can also be related to the study of El Hosary et al. (2018) which is: "The Study of Local Distinctiveness-Through Tangible \& Intangible Aspects of Urban Spaces". This study stated that local distinctiveness encompasses the uniqueness of physical, social and economic characteristics of a place and people's interaction with those characteristics. To be recognized for a particular character, places require variety and diversity.

\subsubsection{Different Perception \\ Cultural Activities}

Cultural activities create "meaning" and embody the identity and values of the city. There are inextricably linked to innovation and creativity, and historically, this has often enabled cities to survive and adapt. A positive image can be created from a strong culture and can be inextricably linked to the image of place (Landry 2002). Cultural activities often relate to regular occasions in religious places in Chiang Mai, the Chedi Luang temple (Figure 7c) was recalled the most in relation to cultural activities. Located in the center of the city and with a strong reputation, many participants identified its merits and use for Buddhist ceremonies (Figure 8). Notably, the Inthakin Festival (Figure 9), also known as the City Pillar Festival, takes place over eight days, beginning on the twelfth day of the waning moon of the sixth lunar month. City Pillars are important to the Thai community, housing the city's guardian spirit, which protects its citizens with Chiang Mai being the only place in Thailand that actually holds the City Pillar Festival (Ongsakul et al. 2005). 


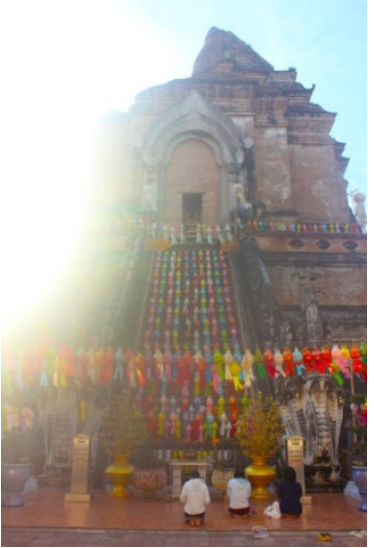

(a)

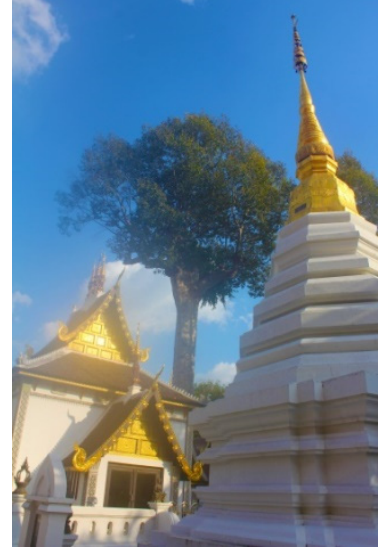

(b)

Figure 8. (a) The Pagoda of Chedi Luang Temple represented to the cosmological belief of urban planning as "the central of universe" (Author). (b) The relationship of City Pillar Shrine and the Spiritual of Ancient Yang Tree (Author).

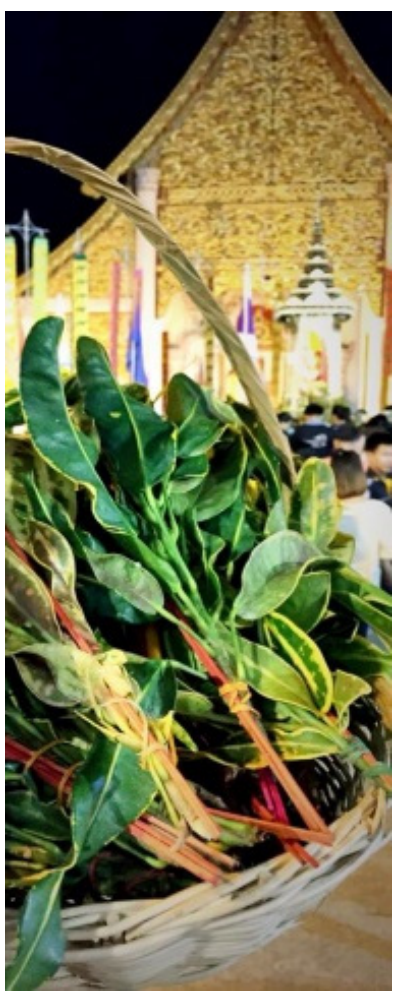

(a)

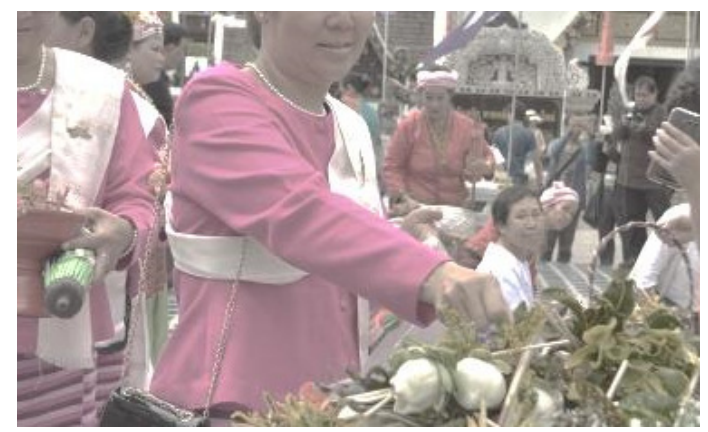

(b)

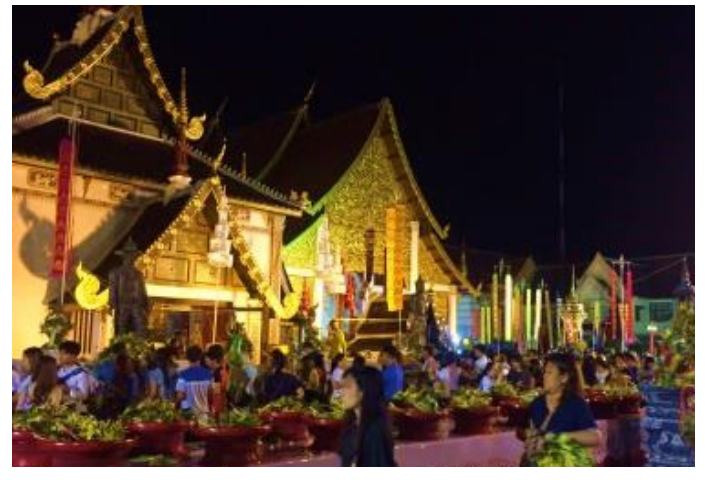

(c)

Figure 9. (a) Holy leaf and flower with one candle and three incenses for the rite (Author). (b) Local People wears Lanna traditional dress for the religion event (Author); (c) Inthakin Festival (Pray to City Pillar) (Author).

\subsubsection{Everyday Life}

The result of this part reflects the significance of urban space to local people in everyday life. Everyday life comprises "seemingly unimportant activities and is a set of functions connecting and joining together systems that might appear to be distinct. The everyday is that which remains after one has eliminated all specialized activities ... everyday space lies in between such defined and physically definable realms as the home, the workplace and the institution, it is the connective tissue that binds everyday lives 
together" (Upton 2002, p. 707). In the questionnaire survey, most of the local people mentioned the Tha-Pare Gate Square (Figure 7a) with regards to its importance to everyday life. Tha Pare Gate Square (Figure 7a) is the most attractive place for local people and tourist according to its location and the activities occurring in the space. The significance of this area is the connection between Tha-Pare Gate Square (Figure 7a) with the walkway of the Chiang Mai City Moat (Figure $6 b, c)$, creating a major junction full of traffic in Chiang Mai Old City. However, most of the participants mentioned its everyday life aspect, such as being "on the route for work" and "see the place while I drove in the city" These results relate to those of Neve $(2018$, p. 165) who mentions the places of our everyday life: "the streets of our town, workplaces, home, squares and monuments, and so on -are naturalized by cultural habits, routines, meanings acquired by education or social relations."

\subsection{Focus Group Results}

The two-way focus group allowed the participants discuss the following topics: (i) What is the distinctiveness of the urban heritage of Chiang Mai Old City?; and (ii) What are the places in the Old City that are important to you? They were also asked to articulate why these can help define the urban heritage identity of the Old City? The results will be discussed in relation to $\mathrm{b}$ Chiang Mai's tangible and intangible heritage

\subsubsection{Landmark}

Lynch (1960, pp. 78-79) identifies that the key physical characteristic of a landmark is a singularity with "some aspect that is unique or memorable in the context". The first group surveyed in this research mentioned that "the uniqueness of local raw materials (brick) on city wall and forts represented the landmark of place and leads local people to disguise the landmark of place" However, the second group also added the significance of the Chiang Mai City Moat, gates and forts, stating that: "If we talk about what we recognize and see when traveling around the city, it would be the moat, the gates and the forts because once we give the direction to someone, we always mention these urban artefacts to give them the sense of direction". The results relate to Lynch's (1960) references to "spatial prominence". Some elements may be established as landmarks by making the element visible from several locations and by providing a local contrast to the surrounding elements. Both groups could define the landmark aspect following their experiences associated with the city; however, both groups discussed the historical artefacts, which are completely disguised from other urban elements.

\subsubsection{Uniqueness \\ Historical Value}

Historical value is the impartial evaluation of experts in deciding which locations is relevant (Wells 2010). Both of the focus groups did not mention a specific building but suggested that the whole site represented the city's historical value aspect. Indeed, there were statements like: "The archaeological sites in Chiang Mai Old City reflect the value of Lanna history" and the "Timeline of architects and buildings in the city could define the history of place." This suggests that local people can acknowledge the architectural timeline of the city. They also agreed that the local government did not sufficiently promote the knowledge of the valuable places or architecture in the Old City until the Chiang Mai Heritage Team attempted to engage with the local community to promote community craft ahead of the UNESCO nomination.

\section{Identity}

Regarding identity, researchers are concerned with the opinions expressed by participants. There were several specific mentions of the word "identity" in the focus groups, with the first group describing the: "Whole body of the city representing the identity of Chiang Mai Old City"; and that "The building style of the temples provides a narrative of the way of life of people, the extraordinary space which appears in those buildings also tells the 
story from the past to present of Lanna identity". However, the second focus group said that the physical features and social life in the city were inextricably linked. They noted that the "identity is represented through our own spiritual being, however, the physical features and social life in the city are also the image of the city which consists of the red truck (Rod Dang - the main vehicle of transportation in Chiang Mai), the uniqueness of the Chiang Mai people's personality which is described as shy, and speaking politely and softly. Nevertheless, it also includes the Northern Thai food, cultural and unique style of clothes." According to these responses, it can be seen that the urban identity is intimately tied to local people's memories. In a similar vein, Hayden (1995, p. 9) refers to urban landscapes as a "storehouse" for social memories with the whole experiences of place being constituted of the interaction between the activity, form and meaning. The definition of the identity of $t$ Chiang Mai Old City's urban heritage is therefore embodied in the memories of the city combined with the spiritual attachment of the local people who create the character activities and life of the city.

\subsubsection{Particular Character}

The particular is concerned with the interchangeability of place usage. Sadowski (2017, p. 127) suggests that the intangible characteristics of "cultural heritage, carries a meaning broader than a "cultural object" and also that there are "other markers of national or group identity, such as intangibles, language, traditional cultural expressions, folklore, genetic recourses and intellectual property." In the focus group discussion, the second group mentioned that "Northern Thai food is the signature dish which tells the story of the history and culture. Furthermore, the northern costumes which we wore since we were young and have worn as part of school regulations every Friday are also a key part of the city's character." The group also identified how they " ... see the difference of the regional costume in Northern provinces, people still wear it in everyday life but, once I went to Bangkok everyone asked me whether I had just joined a wedding reception? Or why do you dress like an old lady?" These observations reflect that the City's cultural heritage can appear through the spirit of the represented people in each space that they have visited (Figure 10). Moreover, the first group also mentioned the importance of crafts in the local community of Chiang Mai Old City which represent the significance of crafts to cultural heritage. The groups commented that the "crafts in the North are unique and hidden amongst the community in the alleys of Chiang Mai Old City." They also noted that: "There are lot of craftsmanship communities with trades such as Goldsmiths (Chang Thong), a painter (Chang Tam), a gong maker (Gong is a metal plate hanging in temples, use as a clock and announcement sound for communities) (Chang Gong) and Northern hair pins decorated with golden flowers (Dok Mai Wai). These are the artefacts which are unintentionally combined with the society, place, space and community of the Old City.

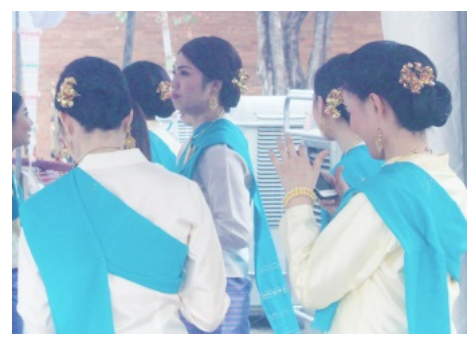

(a)

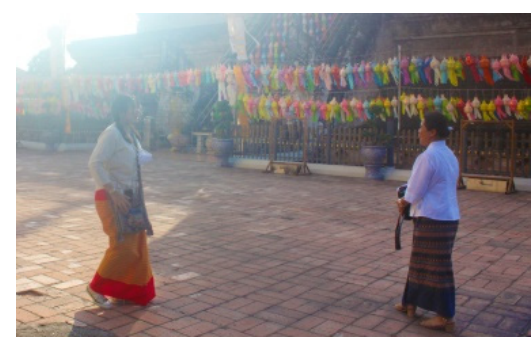

(b)

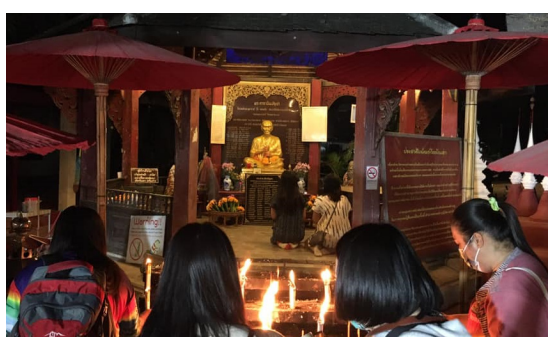

(c)

Figure 10. (a) Lanna traditional performers in Lanna tradition costume (Author). (b) Thai tourists in Lanna dresses (Author). (c) Group of people make merits in a temple (Author). 


\subsubsection{Different Perception}

\section{Cultural Activities}

Local distinctiveness is related to a cultural activity that is an inextricable tie between the city's imaginative art and culture (Landry 2002). In the culture of cities, festivals occupy a special place in human culture and Perry et al. (2020, p. 607) argue that "a 'festival' is thought to be distinguishable from other cultural programs by an intensity of event frequency that would be considered unsustainable year-round, particularly when held across a range of venues". Both focus groups expressed similar experiences with regard to the main festival of Chiang Mai Old City and they specifically mentioned the Inthakin festival in relation to cultural activities. Indeed, there were several statements like: "I join the Inthakin festival every year at Chedi Luang Temple (Figure 7c)" and "If I could pick any place for make merit, it would be in the Old City rather than other". Discussing the meaning of the festival, it was stated that "the main idea of Inthakin is to worship the pillar of the city by using flowers (Kun Dok), ... in the past a lot of people who lived in the community grew many types of the lucky flower bushes (Thai belief) in front of their house and used these flowers for the ceremony and to share with the neighborhood". (Figure 9) Following the focus group discussions, it can be recognized that Chiang Mai people identified the festival and its importance to the Old City's cultural activities. Perry et al. (2020) explained the inherent relationship between festivals and physical spaces in forming the tangible heritage of a place. Moreover, the place identity and value of place can be defined and supported by the festival; however, the happening of the festival has potentially transformed the locations and spaces following social, cultural and place-based significance.

\subsubsection{Community}

Community identities are important as they can inspire a feeling of pride, self-respect, unity, sense of place and social responsibility for local people (Ratanakosol et al. 2016). The first focus group explained the community's feeling in Chiang Mai Old City as “... community still strong enough to survive in the change of economic but I feel regret when I saw everyone change their identity for serving a tourism industry. It would be great if the council support their community heritage careers". In addition, one of the second group participants mentioned her pride in the city, stating that: "I feel proud with my city and proud to tell everyone that I live here." She also added that: "I think Chiang Mai people retain their way of life from the past and still have their Lanna spirit and it is important that local people still join the cultural activities, follow traditions and have adapted these to the current situation." Participants in the second focus group also mentioned the importance of community identity from an economic perspective. They defended the first statement of the first group, stating that: "Local people retain the vital aspect to increase the identity and economy in the old city because they have learned how to use the old things commercially and to preserve them for the community's advantage." These findings can be related to the study of Ketz and Moe (2012) that identified a community's sustainable economic concerns through the formation of viable partnerships that linked various financial instruments to heritage. This approach can strengthen a community's identity; however, it can also create economic stimulation that can challenge the authenticity of place.

\section{Discussion}

According to the questionnaire results, the people of Chiang Mai recalled most was the Pra Singha temple (Figure $7 \mathrm{~b}$ ) located on the main axis of the Old City. The place was recalled the most in relation to its historical value. Furthermore, many participants also recalled positive memories of the Chedi Luang temple (Figure 7c), which is located in the center of cosmological Hindu-Buddhist belief, in relation to its cultural activities. Moreover, it is a prominent place for urban cultural activities which reflect social life related to religion and belief, such as the Song Kran festival, Thai New Year festival and the Inthakin Festival. From the aspects of landmarks and particular character, the Three Kings Monument Square 
(Figure 6a), in the city center, was strongly recalled by the participants. Many stated that this urban open location and character induced people to participate in multiple activities in this square. Besides, in relation to everyday life, Tha-Pare Gate Square (Figure 7a) was mentioned due to its location. It was also identified and the most important place in the Old City in relation to the identity of the place with the Chiang Mai City Moat (Figure 6b,c).

The focus groups played a key part in generating an in-depth understanding of the Chiang Mai people's awareness and attachment to the urban heritage of the Old City (see Table 6). As such, the results from both groups have contributed the genuine local expression and the depth of reasons to the topic and strengthened the knowledge of the distinctiveness of place. The outcomes can be divided into the six aspects (see Table 7), firstly, the landmarks, where the discussion highlighted the importance of "local materials on urban heritage as a landmark to help give a sense of direction while living in the city." In relation to the historical value and identity, the overall Chiang Mai Old City itself was described as significant as representing the "spirituality of the people". Interestingly, the particular character aspects mentioned focused on the traditional Chiang Mai costumes representing the City's pride and spread awareness of Chiang Mai's identity to other cities. In relation to cultural activities, the Inthakin Festival was articulated as the most important in terms of its significance as tangible heritage displayed through the City's spaces. Finally, the community aspect was given primary importance by the groups who mentioned the strong "spirit of the community that boned the city and created a sustainable community economic strategy" within Chiang Mai Old City.

Table 6. The result of focus group analysis.

\begin{tabular}{|c|c|c|c|c|c|}
\hline \multicolumn{6}{|c|}{ Group: Distinctiveness of Urban Heritage of Chiang Mai Old City, Thailand } \\
\hline \multicolumn{2}{|c|}{ Subgroup: Urban factors } & \multicolumn{3}{|c|}{ Subgroup: Culture and Tradition } & \multirow{2}{*}{$\begin{array}{c}\begin{array}{c}\text { Subgroup: Human } \\
\text { factors }\end{array} \\
\text { Community }\end{array}$} \\
\hline Landmark & Identity & Historical Values & Cultural Activities & Particular Characters & \\
\hline $\begin{array}{l}\text { "the uniqueness of local } \\
\text { raw materials (brick) on } \\
\text { city wall and forts } \\
\text { represented the } \\
\text { landmark of place and } \\
\text { leads local people to } \\
\text { disguise the landmark } \\
\text { of place"(G1L) } \\
\text { "If we talk about what } \\
\text { we recognize and see } \\
\text { when traveling around } \\
\text { the city, it would be the } \\
\text { moat, the gates and the } \\
\text { forts because once we } \\
\text { give the direction to } \\
\text { someone, we always } \\
\text { mention these urban } \\
\text { artifacts to give them } \\
\text { the sense of direction" } \\
\text { (G2L) }\end{array}$ & $\begin{array}{l}\text { "Whole body of the city } \\
\text { representing the } \\
\text { identity of Chiang Mai } \\
\text { Old City"(G1I) } \\
\text { "The building style of } \\
\text { the temples provides a } \\
\text { narrative of the way of } \\
\text { life of people, the } \\
\text { extraordinary space } \\
\text { which appears in those } \\
\text { buildings also tells the } \\
\text { story from the past to } \\
\text { present of Lanna } \\
\text { identity" (G1I) } \\
\text { "identity is represented } \\
\text { through our own } \\
\text { spiritual being, } \\
\text { however, the physical } \\
\text { features and social life } \\
\text { in the city are also the } \\
\text { image of the city which } \\
\text { consists of the red truck } \\
\text { (Rod Dang - the main } \\
\text { vehicle of transportation } \\
\text { in Chiang Mai), the } \\
\text { uniqueness of the } \\
\text { Chiang Mai people's } \\
\text { personality which is } \\
\text { described as shy and } \\
\text { speaking politely and } \\
\text { softly. Nevertheless, it } \\
\text { also includes the } \\
\text { Northern Thai food, } \\
\text { cultural and unique } \\
\text { style of clothses." } \\
\text { (G2I) }\end{array}$ & $\begin{array}{l}\text { "The archeological } \\
\text { sites in Chiang Mai } \\
\text { Old City reflect the } \\
\text { value of Lanna } \\
\text { history" (G1HV) } \\
\text { (G2HV) } \\
\text { "Timeline of } \\
\text { architects and } \\
\text { buildings in the city } \\
\text { could define the } \\
\text { history of place." } \\
\text { (G1HV) (G2HV) }\end{array}$ & $\begin{array}{c}\text { "I join the Inthakin } \\
\text { festival every year at } \\
\text { Chedi Luang Temple" } \\
\text { (G1CA) } \\
\text { (G2CA) } \\
\text { "If I could pick any } \\
\text { place for make merit, it } \\
\text { would be in the Old } \\
\text { City rather than other" } \\
\text { (G1CA) } \\
\text { (G2CA) } \\
\text { "the main idea of } \\
\text { Inthakin is to worship } \\
\text { the pillar of the city by } \\
\text { using flowers (Kun } \\
\text { Dok), ... in the past a } \\
\text { lot of people who lived } \\
\text { in the community grew } \\
\text { many types of the lucky } \\
\text { flower bushes (Thai } \\
\text { belief) in front of their } \\
\text { house and used these } \\
\text { flowers for the } \\
\text { ceremony and to share } \\
\text { with the } \\
\text { neighbourhood." } \\
\text { (GDCA) }\end{array}$ & $\begin{array}{l}\text { "Northern Thai food is the } \\
\text { signature dish which tells } \\
\text { the story of the history and } \\
\text { culture. Furthermore, the } \\
\text { northern costumes which we } \\
\text { wore since we were young } \\
\text { and have worn as part of } \\
\text { school regulations every } \\
\text { Friday are also a key part of } \\
\text { the city's character." (G2PC) } \\
\text { ". . see the difference of the } \\
\text { regional costume in } \\
\text { Northern provinces, people } \\
\text { still wear it in everyday life } \\
\text { but, once I went to Bangkok } \\
\text { everyone asked me whether } \\
\text { I had just joined a wedding } \\
\text { reception? Or why do you } \\
\text { dress like an old lady?" } \\
\text { (G2PC) } \\
\text { “crafts in the North are } \\
\text { unique and hidden amongst } \\
\text { the community in the alleys } \\
\text { of Chiang Mai Old City." } \\
\text { (G1PC) } \\
\text { “There are lot of } \\
\text { craftsmanship communities } \\
\text { with trades such as } \\
\text { Goldsmiths (Chang Thong), } \\
\text { Painting (Chang Tam), Gong } \\
\text { (Chang Gong), Northern } \\
\text { hair pins decorated with } \\
\text { golden flowers (Dok Mai } \\
\text { Wai). These are the artifacts } \\
\text { which are unintentionally } \\
\text { combined with the society, } \\
\text { place, space and community } \\
\text { of the Old City.” (G1PC) }\end{array}$ & $\begin{array}{l}\text { “. community still } \\
\text { strong enough to } \\
\text { survive in the change of } \\
\text { economic but I feel } \\
\text { regret when I saw } \\
\text { everyone change their } \\
\text { identity for serve a } \\
\text { tourism industry. I } \\
\text { would be great if the } \\
\text { council support their } \\
\text { community heritage } \\
\text { careers" (G1C) } \\
\text { "I feel proud with my } \\
\text { city and proud to tell } \\
\text { everyone that I live } \\
\text { here." (G2C) } \\
\text { "I think Chiang Mai } \\
\text { people retain their way } \\
\text { of life from the past and } \\
\text { still have their Lanna } \\
\text { spirit and it is important } \\
\text { that local people still } \\
\text { join the cultural } \\
\text { activities, follow } \\
\text { traditions and have } \\
\text { adapted these to the } \\
\text { current situation." } \\
\text { (G2C) } \\
\text { "Local people retain the } \\
\text { vital aspect to increase } \\
\text { the identity and } \\
\text { economy in the old city } \\
\text { because they have } \\
\text { learned how to use the } \\
\text { old things commercially } \\
\text { and to preserve them } \\
\text { for the community's } \\
\text { advantage." (G2C) }\end{array}$ \\
\hline
\end{tabular}


Table 7. The conclusion of the recollection to the important places in Chiang Mai Old City.

\begin{tabular}{clll}
\hline Rank & \multicolumn{1}{c}{ Aspects } & \multicolumn{1}{c}{ Place } & \multicolumn{1}{c}{ Typical Words from Participants to Places } \\
\hline 1 & Historical Value & Pra Singha Temple & $\begin{array}{l}\text { Ancient place, Important place; historical traveling; } \\
\text { conservation place; realized by historical location; } \\
\text { knowledgeable place; activities place }\end{array}$ \\
\hline 2 & Cultural Activities & Chedi Luang Temple & $\begin{array}{l}\text { Pray to the Buddha; Inthakin Festival; make merit; } \\
\text { lighting candles for blessing; pagoda; special festival; } \\
\text { visited for a special religion ceremony }\end{array}$ \\
\hline 3 & Particular Character & $\begin{array}{l}\text { Three Kings Monument } \\
\text { Square }\end{array}$ & $\begin{array}{l}\text { Located in neighborhood; childhood memories; } \\
\text { merchandise; good place for food; activities space; place } \\
\text { for traveling }\end{array}$ \\
\hline 5 & Everyday life & Tha-Pare Gate Square & On the route to work; had visited the place; see the place \\
\hline 6 & Landmark & $\begin{array}{l}\text { Three Kings Monument } \\
\text { Square }\end{array}$ & $\begin{array}{l}\text { Landmark; memories of Chiang Mai; traveller landmark; } \\
\text { easy to find the place }\end{array}$ \\
\hline & Identity & $\begin{array}{l}\text { Tha-Pare Gate Square and } \\
\text { Chiang Mai City Moat }\end{array}$ & Identity; image of Chiang Mai City; reputation value \\
\hline
\end{tabular}

\section{Conclusions}

The results and findings from this research are significant because they expand upon the aspects discussed in the literature in relation to defining the distinctiveness of a city. In comparison with the previous research of El Hosary et al. (2018) and Ginting and Wahid (2017), this research proposes similar aspects to define the distinctiveness of the city. Specifically, seven aspects were found to further narrow down Chiang Mai Old City's urban heritage management plan including its landmarks, historical value, identity, particular character, cultural activities, everyday life and community. The outcomes of the quantitative and qualitative proposed the stronger belief from local people perception of the city. Most participants interpreted to the city as "Historical Values" and "Culture Activities "aspects." They feel attached to religious places and the uniqueness of the urban city planning which is relevant to the Chiang Mai Heritage Team in the dossier. However, in addition, new aspects, which consist of the community aspect and the everyday life aspect, emerged in defining the urban heritage of the living city.

Nevertheless, the theory would be suitable for the assessment and comparison of the initial perception of places. The research results can help the development and promotion of a more thorough understanding of Chiang Mai Old City, which can then inform more contextually relevant and sustainable strategies for the management of the city. Indeed, the significance of understanding the local distinctiveness can increase awareness of the unique character of the historic environment from the perspective of the local community's perception. As such, the results of this research, through an investigation of local people's perception, demonstrate the importance of engaging communities in defining the distinctiveness of heritage areas in South East Asia countries.

Author Contributions: The research carried out the urban heritage identity studies, particularly in the sequence alignment and draft manuscript. The study focused on defining the distinctiveness of urban heritage in an extraordinary context. The qualitative and quantitative methods have been used in the study, consisting of interviews, questionnaires, and two-way focus groups. Supervision, T.H.; Writing-review \& editing, T.H.; N.P. All authors have read and agreed to the published version of the manuscript.

Funding: This study received Chiang Mai University Scholarship.

Institutional Review Board Statement: Ethical approval was approved by the Ethical Committee of Faculty of Engineering, University of Nottingham, Nottingham, UK.

Informed Consent Statement: Informed consent was obtained from all subjects interviewed in the study. 
Data Availability Statement: All data in this study are publicly available.

Acknowledgments: I am grateful to Tim Heath for his support and believe in my ability and also grateful to the anonymous reviewers, who made several valuable suggestions.

Conflicts of Interest: The authors declare no conflict of interest.

\section{References}

Arbak, Sebnem. 2005. An Analysis on the Transformation of Urban Identity. CASE STUDY OF BODRUM. Ankara: Middle East Technical University.

Boussaa, Djamel. 2017. Urban regeneration and the search for identity in historic cities. Sustainability 10: 48. [CrossRef]

Carmona, Matthew, Tim Heath, Steve Tiesdell, and Taner Oc. 2010. Public Places Urban Spaces. London: Routledge.

Cheshmehzangi, Ali, and Tim Heath. 2012. Urban Identities: Influences on Socio-Environmental Values and Spatial Inter-Relations. Procedia-Social and Behavioral Sciences 36: 253-64. [CrossRef]

Cultural and Natural Environment Management Bureau. 2016. Available online: http:/ /www.onep.go.th/nced/?p=1194 (accessed on 1 October 2020).

Devine-Wright, Patrick. 2009. Rethinking NIMBYism: The role of place attachment and place identity in explaining place-protective action. Journal of Community \& Applied Social Psychology 19: 426-41.

El Hosary, O., A. Sarhan, and Y.A. Farghaly. 2018. The Study of Local Distinctiveness-Through Tangible In addition, Intangible Aspects Of Urban Spaces. International Journal of Research in Engineering and Technology 7: 101-6.

Erdoğan, Başak Damla, and Hatice Ayataç. 2015. Assessment of urban identity characteristics in public places: A case study of Ortaköy Square. ITU Journal of the Faculty of Architecture 12: 115-25.

Ginting, Nurlisa, and Julaihi Wahid. 2017. Defining Distinctiveness Aspect of Place Identity in Urban Heritage Tourism. IPTEK Journal of Proceedings Series. [CrossRef]

Hartanti, Nurhikmah Budi. 2014. Maintaining the Urban Identity by Managing Streetscapes Character of Bogor City. International Conference on Urban and Regional Planning, 1-9.

Hayden, Dolores. 1995. The Power of Place: Urban Landscapes as Public History. Cambridge: The MIT Press.

Howard, Peter. 2003. Heritage: Management, Interpretation, Identity. London: Continuum Publishing.

Huang, Mu-Hsuan, and Chi-Shiou Lin. 2011. Counting Methods, Country Rank Changes and Counting Inflation in the Assessment of National Research Productivity and Impact. Journal of the American Society for Information Science and Technology 62: 2427-36. [CrossRef]

Johnson, Andrew Alan, M. Hickey, and T. Bunnell. 2013. Kheut: Revisiting, Recasting and Reinterpreting Northern Thai Architectural Taboos. Singapore: Asia Research Institute Publication, National University of Singapore, p. 195.

Kalandides, Ares. 2011. The problem with spatial identity: Revisiting the "sense of place". Journal of Place Management and Development 4: 28-39. [CrossRef]

Ketz, Anne, and Nathan Moe. 2012. Leveraging Cultural Heritage for Community Identity and Economic Development. Available online: https:/ /106group.com/wp-content/uploads/2012/09/MnAPA-Paper-106-Group-9-2012.pdf (accessed on 1 October 2020).

Lalli, Marco. 1992. Urban-related identity: Theory, measurement and empirical findings. Journal of Environmental Psychology 12: 285-303. [CrossRef]

Landry, Charles. 2002. The Creative City. Available online: http://www.reading.ac.uk/AcaDepts/kc/CMandE/PeBBu/state_of_art/ urban_approaches/creative_city/creative_city.htm (accessed on 1 October 2020).

Logan, William. 2005. Museums, Community Identity and Urban Heritage. Queensland Review 12: 27-35. [CrossRef]

Lynch, Kevin. 1960. The Image of the City. Cambridge: MIT Press.

Marshall, Catherine, and Gretchen B. Rossman. 2003. Designing Qualitative Research. Newbury Park: Sage.

Martínez, Plácido González. 2017. Urban authenticity at stake: A new framework for its definition from the perspective of heritage at the Shanghai Music Valley. Cities 70: 55-64. [CrossRef]

Moe, Kyaw Zwa. 2001. Chiang Mai Is Losing Its “Green and Clean”. Available online: https://www2.irrawaddy.com/article.php?art_ $\mathrm{id}=2411$ (accessed on 3 June 2019).

Neve, Mario. 2018. Would Urban Cultural Heritage Be Smart? Culture as a Land Factor in addition, Italian Citie. Smartness. Journal of Communication and Languages 48: 163-90.

Nili, Alireza, Mary Tate, and David Johnstone. 2017. A framework and approach for analysis of focus group data in information systems research. Communications of the Association for Information Systems 40: 1-21. [CrossRef]

Nyumba, Tobias O., Kerrie Wilson, Christina J. Derrick, and Nibedita Mukherjee. 2018. The use of focus group discussion methodology: Insights from two decades of application in conservation. Methods in Ecology and Evolution 9: 20-32. [CrossRef]

Ongsakul, S., D. Millar, and S. Barron. 2005. History of Lan Na. Chiang Mai: Silkworm Books.

Orbasli, Aylin. 2000. Tourists in Historic Towns: Urban Conservation and Heritage Management. London and New York: Spon Press, Korean Edition Published, 2012.

Perry, Beth, Laura Ager, and Rike Sitas. 2020. Cultural heritage entanglements: Festivals as integrative sites for sustainable urban development. International Journal of Heritage Studies 26: 603-18. [CrossRef] 
Proshansky, Harold M., H. K. Fabian, and R. Kaminoff. 1983. Place identity: Physical world socialisation of the self. Journal of Environmental Psychology 3: 57-83. [CrossRef]

Ratanakosol, Kulthid, Wiratep Pathumcharoenwattana, and Pan Kimpee. 2016. Learning process for creating community identity. SHS Web of Conferences 26: 01067. [CrossRef]

Relph, Edward. 2007. On the Identity of Places. In Urban Design Reader. Edited by Steve Tiesdell and Matthew Carmona. Oxford, UK: Architectural Press, pp. 102-7.

Rifaioğlu, Mert Nezih, and Neriman Şahin Güçhan. 2007. The Concept of Identity and Its Identification Process in Urban Conservation Projects. Paper presented at the An International Conference of CSAAR on Regioal Architecture and Identity in the Age of Globalization, Tunis, Tunisia, November 13-15.

Rowley, Jenny. 2011. Designing and Using Research Questionnaires. Management Research Review. [CrossRef]

Sadowski, Mirosław M. 2017. Urban Cultural Heritage: Managing and Preserving a Local Global Common in the Twenty-first Century. Journal of Heritage Management 2: 125-51. [CrossRef]

Shamsuddin, Shuhana. 1997. Identity of Place: A Case Study of Kuantan Town Centre, Malaysia. Ph.D. dissertation, University of Nottingham, Nottingham, UK.

Shinbira, Ibrahim. 2017. Defining Place Identity: Misurata, Libya. Ph.D. dissertation, University of Nottingham, Nottingham, UK.

Srinurak, Nattasit, and Nobuo Mishima. 2017. Urban Axis and City shape evaluation through spatial configuration in 'Lan Na' Northern Thailand Historic city. City, Territory and Architecture 4. [CrossRef]

Srinurak, N., and S. Auttarat. 2013. The Study of Resident Behavior in Modification of Building Façade to Provide Building Guideline in Chiang Mai Old Town Study Area Thapae Road (Garn-Suk-Sar-Prut-Ti-Gum-Garn-Tor-Term-Darn-Nah-Arkarn-Puea-Jad-Garn-Naw-Tang-GarnKoubkum-Darn-Nah-Arkarn-Nai-Puenti-Muanggao-ChaingMai (In Thai). Final Report. Chiang Mai: Social Research Institute Chiang Mai University.

Thai PBS. 2020. คุ้มเวียงแก้ว" ความสำคัญในอดีต สู่การใช้พื้นที่ขนาดใหญ่กลางเมืองเชียงใหม่ . Kum-Luang-Vieng-Keaw-Kuam-Sum-KunNai-Ar-deed-Su-Karn-Chai-Puen-Thi-Kanard-Yai-Grang-Muang-Chiang Mai. (In Thai). Available online: https://news.thaipbs. or.th/content/295756 (accessed on 1 October 2020).

The Bureau of Registration Administration of Thailand. 2019. Number of Population in Thailand. Available online: https://housingkc. nha.co.th/files/article/attachments/ffaef8523776e58763edecf0906c208e.pdf (accessed on 3 February 2020).

Tunprawat, Patcharawee. 2009. Managing Living Heritage Sites in Mainland Southeast Asia. Nakhon Pathom: Silpakorn University, Available online: https:/ tci-thaijo.org/index.php/damrong/article/download/21873/18861/ (accessed on 1 October 2020).

Twigger-Ross, Clare L., and David L. Uzzell. 1996. Place and identity processes. Journal of Environmental Psychology 16: 205-20. [CrossRef]

UNESCO. 2020. UNESCO World Heritage Centre-Tentative Lists, from Whc.unesco.org. Available online: https:/ / whc.unesco.org/ en/tentativelists / state=th (accessed on 16 June 2020).

Upton, Dell. 2002. Architecture in Everyday Life. New Literary History 33: 707-23. [CrossRef]

Urban Heritage. 2016. Available online: https://scth.gov.sa/en/Heritage/Pages/UrbanHeritage.aspx (accessed on 21 December 2020).

Vignoles, Vivian L., Xenia Chryssochoou, and Glynis M. Breakwell. 2000. The Distinctiveness Principle: Identity, Meaning and the Bounds of Cultural Relativity. Personality and Social Psychology Review 4: 337-54. [CrossRef]

Wells, Jeremy C. 2010. Valuing Historic Places: Traditional and Contemporary Approaches. Bristol: School of Architecture, Art and Historic Preservation, Roger Williams University, pp. 1-15. Available online: http://docs.rwu.edu/saahp_fp/22/ (accessed on 1 June 2020).

Werayutwattana, Tus. 2019. Our Journey to Chiang Mai Becoming A UNESCO World Heritage City, Chiang Mai City Life. Available online: https:/ / www.chiangmaicitylife.com/clg/our-city/journey-becoming-unesco-world-heritage-city (accessed on 1 March 2020).

Yamane, Taro. 1967. Statistics: An Introductory Analysis, 2nd ed. New York: Harper and Row. 